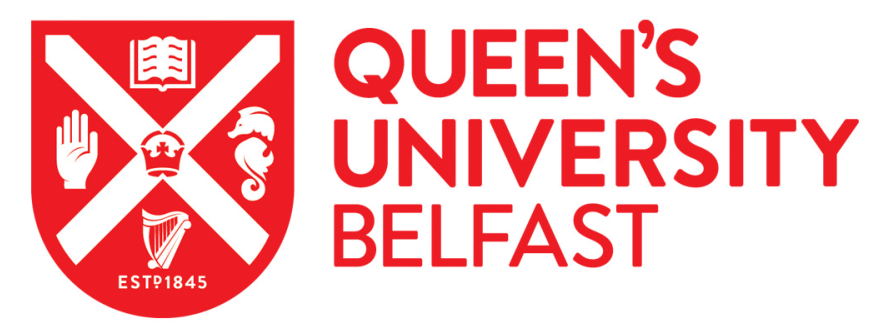

\title{
Management accounting routines: a framework on their foundations
}

Quinn, M., \& Hiebl, M. (2018). Management accounting routines: a framework on their foundations. Qualitative Research in Accounting \& Management, 15(4), 535-562. https://doi.org/10.1108/QRAM-05-2017-0042

Published in:

Qualitative Research in Accounting \& Management

Document Version:

Peer reviewed version

Queen's University Belfast - Research Portal:

Link to publication record in Queen's University Belfast Research Portal

Publisher rights

(c) 2018 Emerald Publishing Limited. This work is made available online in accordance with the publisher's policies. Please refer to any applicable terms of use of the publisher.

\section{General rights}

Copyright for the publications made accessible via the Queen's University Belfast Research Portal is retained by the author(s) and / or other copyright owners and it is a condition of accessing these publications that users recognise and abide by the legal requirements associated with these rights.

Take down policy

The Research Portal is Queen's institutional repository that provides access to Queen's research output. Every effort has been made to ensure that content in the Research Portal does not infringe any person's rights, or applicable UK laws. If you discover content in the Research Portal that you believe breaches copyright or violates any law, please contact openaccess@qub.ac.uk. 


\section{Management accounting routines: a framework on their foundations}

\section{Structured Abstract}

Purpose: Recent research provides useful insights on management accounting routines, yet little is written on their foundations. In particular, factors which may contribute to eventual management accounting routines have not been detailed in terms of the process of routinization. Thus, this paper aims to provide an initial theory-based understanding on the foundation of management accounting routines. In turn, it is hoped this will raise further research interest on this topic.

Design/methodology/approach: Drawing on extant literature, a framework on foundations of management accounting routines is developed, and two empirical cases illustrate its operationalisation.

Findings: The framework illustrates that a more complete understanding of change to management accounting routines can be gleaned when more is known about their foundations. The foundations are likely to be influenced by a combination and/or interaction of factors at (i) the organizational level, (ii) the organizational field level and (iii) the economic and political level.

Research limitations/implications: Due to our so far limited understanding of the foundation of management accounting routines, more research is required. Our framework may be useful to guide such research.

Originality/value: To the best of our knowledge, this is one of few papers to offer an initial theory-based understanding on the foundations of management accounting routines specifically. This understanding can be built on to improve our knowledge in the management accounting domain of the complex, but ubiquitous concept, of organizational routines.

Keywords: Management accounting, Routines, Foundations

Paper type: Research paper 


\section{Introduction}

Much has been written on organizational routines and they are perceived as one of the fundamental building blocks of organizational activities (Pentland et al., 2010) and contribute to research in many areas of organizational life, including management accounting. Indeed, management accounting researchers have drawn on routines to explain the relatively stable, but simultaneously changing nature of management accounting practices (see for example, Burns and Scapens, 2000; Busco and Scapens, 2011; Fiondella et al., 2016; Lukka, 2007; Quinn, 2011; Scapens, 2006; van der Steen, 2009, 2011). This extant research on management accounting routines has contributed significantly to our understanding of management accounting change and stability.

That organisations comprise sets of routines is generally accepted in organizational theory (see for example, Kilduff, 1992), and studying these is of merit "to understand routines is to understand organisations" (Becker, 2008, p. 1). Many studies enlighten our understanding of organizational routines as a concept (see for example, Becker, 2005; Feldman and Pentland, 2003; Pentland, 2011) and have been drawn upon by management accounting scholars (see for example Busco and Scapens, 2011; van der Steen, 2009, 2011; Quinn, 2011, 2014). Kilduff (1992) suggests if we can understand how routines are produced, we can predict some things about the organisation. Taking this to a management accounting realm, it is proposed that if knowledge of how management accounting routines emerge is gained, a better understanding of how management accounting is/was formed, shaped, changes or remains stable over time will result. However, extant management accounting literature tends to focus on management accounting routines in-situ, that is, after routines have emerged and are being enacted. While such literature assists our understanding of "programs that produce organizational routines" (Kilduff, 1992, p. 133), it does not detail how and why management accounting routines emerge in the first place. For example, Burns and Scapens (2000) assume rules (i.e., how things should be done) and routines (i.e., how things are done) already exist, and that new management accounting rules and routines are encoded from existing rules and routines - later work by, for example, Dillard et al. (2004), Fiondella et al. (2016), Hassan (2005), Jabbour and Abdel-Kader (2015), 
Lukka (2007), Quinn (2011, 2014), Ribeiro and Scapens (2006), Sharma et al. (2014), Siti-Nabiha and Scapens (2005), Soin et al. (2002), Spraakman (2006) and van der Steen (2009, 2011) takes such assumptions on board. Put differently, as Becker et al. (2005, p. 780) note, "one of the most unsatisfying features of more than two decades of research on organizational routines is the slow progress in understanding how organizational routines emerge", which seems to also apply to management accounting routines. To borrow Kilduff's (1992, p. 133) terminology, the question "How do 'programs that produce organizational routines' form?" could be posed. Or, what are the factors which influence such programs, which in turn influence the nature of the routines which emerge? Combining such questions, we begin to explore the foundations of management accounting routines.

In this paper, a theorization of the foundations of management accounting routines and factors which may contribute to these foundations is given. As already noted, Burns and Scapens (2000) provide a framework which depicts a process of how management accounting practices can become institutionalised, which includes routines, and this has been built on by others. We detail an earlier part of that same process, focusing on factors which may result in management accounting routines; first, an underlying meaning of the term "foundations"; and, then draw on extant literature to derive potential factors which may influence the foundations of routines. These factors are then interwoven with the work of Burns and Scapens $(2000)^{1}$ and theoretical insights on the foundations of organizational routines (e.g., Felin et al., 2012). We finally use two short cases to illustrate interplays of factors in the foundation of management accounting routines. The remainder of the paper is structured as follows. The next section reviews extant literature on organizational routines. In particular, this section highlights the components of routines, micro-foundations of routines, and sets out our meaning of the term "foundations". It also reveals factors from the literature which may cause routines (in general) to emerge. Section 3 provides a framework on how these factors influence the foundations of management accounting routines. This framework presents a more complete

\footnotetext{
${ }^{1}$ Burns and Scapens (2000, p.12) do provide some factors which may influence institutions. We return to this in Section 3.
} 
process of routinization of management accounting, drawing on Burns and Scapens (2000), Felin et al. (2012) and others. Section 4 applies our framework to two illustrative cases to highlight how the framework can be used to empirically examine the foundation of management accounting routines. Finally, Section 5 discusses some implications for on-going research on management accounting routines.

\section{The foundation of routines in management accounting}

Before revealing our process of routinization of management accounting, some relevant extant literature on organizational routines is detailed. From the more general organizational and institutional literature we extract a definition of routines and build up to our meaning of the foundations of routines. Then, literature which gives insights into factors which may represent the foundations of management accounting routines is detailed.

\subsection{Defining organizational routines and their foundations}

As noted in the introduction, this paper aims to provide an understanding of the foundation of management accounting routines. Felin et al. (2012) suggest studies exploring micro-foundations are necessary as academic disciplines progress and seek to explain in detail existing assumptions about a particular field of research. For example, it is widely accepted (see later) that management accounting is a routinized practice; but, at the same time detailed studies of how such routines come about are not plentiful. Thus, for this study we start by drawing on established work to provide accepted definitions of organizational routines. Pentland (2011, pp. 280-281) summarizes much of the extant research to define organizational routines as having four essential components: 1) routines are repetitive, 2) a recognizable pattern of action occurs, 3) actions are interdependent, and 4) multiple actors are involved. Taking these four components, ${ }^{2}$ routines are

\footnotetext{
2 The ostensive dimension of a routine is the tacit element, with the performative being the actual acting out of a routine.
} 
presented as a crucial element of organizational life and a key building-block for stable organizational practices. Although routines are typically associated with stability, they are also a source of change. Work by Feldman and Pentland (2003) provides insights on how change to routines can be brought about. Feldman and Pentland (2003) and Pentland and Feldman (2005, 2008) highlight how interactions within the dimensions of routines - the ostensive and performative - can bring about change but also encompass stability. These works of Feldman and Pentland provide a conceptualization of routines which always have potential for change (at each performance through the performative routine dimension) but yet retain an underlying relatively stable understanding of what the routine is about in the minds of actors (i.e. the ostensive routine dimension).

Taking Pentland's (2011) definition of organizational routines, together with the earlier work of Feldman and Pentland (2003), a useful and detailed understanding emerges which we draw on here. Pentland (2011) allows us to determine if something is a routine or not, essentially a check list of elements of routines. Thus, for example, it cannot be said that an action performed once is a routine, as there is no repetitive action. Pentland draws on Feldman and Pentland (2003), noting "routines exist as a duality of ostensive and performative aspects (or, if you prefer, abstract patterns and specific actions)" (2011, p. 289). Thus, the four elements of an organizational routine as proposed by Pentland (2011) are underpinned by actual behaviour patterns (the performative aspect) and potential behaviours (the ostensive aspect). Pentland's (2011) work supports the broad constructs of other works on organizational routines (Becker, 2008).

Having outlined a definition of routines, we can begin to reveal extant literature on their foundations. First, we should clarify our meaning of "foundation". In contemporary dictionaries, some different but similar meanings are given. For instance, Oxford Dictionaries Online ${ }^{3}$ suggests that "foundation" in a technical meaning is "the lowest load-bearing part of a building", but in a metaphorical meaning stands for "an

\footnotetext{
${ }^{3}$ See http://www.oxforddictionaries.com/definition/english/foundation
} 
underlying basis or principle". Similarly, Merriam Webster ${ }^{4}$ lists foundation as "something (such as an idea, a principle, or a fact) that provides support for something". Etymologically, "foundation" originally stems from the Latin verb fundare (Hoad, 1993; Skeat, 1993), which - according to Oxford Dictionaries Online ${ }^{4}$ - may be translated to contemporary English as "to lay the base for". Given that the metaphorical contemporary meanings of "foundation" in standard English-language dictionaries are variations of this Latin origin, here the term "foundation" in its original meaning of "to lay a base for" is used. In place of "foundation", the term "emergence" could also be used to describe how management accounting routines come about in the first instance. However, we propose emergence as a term applies equally to routines which are in-situ as they evolve (or "emerge") into "new" routines; cf. Feldman and Pentland (2003), who note the omnipresent ability of routines to change at each performance. Using the term "foundation" (but see below), it is recognised that management accounting routines emanate from some baseline (Felin et al., 2012), but as mentioned earlier, the specific factors comprising this baseline are relatively under-researched in a management accounting context.

A body of literature on the micro-foundations of routines, should also be acknowledged and distinguished from our "foundations" meaning here. Abell et al. (2008) note micro-foundations had become an important theme in strategic management research. They suggest the micro-analytical level is that of individuals, while the macro level applies to organisations. They also note the link between these two levels, and suggest a need to explore and explain the micro level to obtain a deeper understanding of macro level concepts such as routines and capabilities. Barney and Felin (2013, p. 140) note there is some amount of disagreement on what micro-foundations are or are not and they suggest several "half-truths and misconceptions associated with micro-foundations", which are worthy of mention. First, they suggest micro-foundations are not solely about individuals, as this would ignore interactions among individuals. They note "the foundations portion of micro-foundations is important in that it places emphasis on the need to specifically understand the

\footnotetext{
${ }^{4}$ See http://www.merriam-webster.com/dictionary/foundation
} 
unique, interactional, and collective effects that are not only additive but also emergent" (Barney and Felin, 2013, p. 141, emphasis added). A second half-truth noted by Barney and Felin (2013) is that microfoundations lead to infinite regress. A key point in this regard is to bear in mind the level of analysis of the study or field, which is typically the organisation, or in our case management accounting. Thus, drawing on Barney and Felin's (2013) words, we could reduce our study to the detailed background of individual management accountants, their entire personal experiences, their employment history and so on, but such vast detail is likely unnecessary to help us understand their activities and behaviours in the organisation and would ignore interactions of management accountants with other individuals. However, some individual experiences may help us understand activities and behaviours - the key point being studies of phenomena need not be reduced to the $\mathrm{n}^{\text {th }}$ degree as suggested by Felin et al. (2012). A third half-truth noted by Barney and Felin (2013) is that micro-foundations deny a role played by structure and institutions. This, they note, is connected to the reduction of analysis to the level of individuals, which as mentioned above may deny the interactions of individuals. This point is also clear in the work of Felin et al. (2012), who specifically mention structure as a micro-foundation of organisational routines and capabilities. Felin et al. (2012) propose three micro-foundations of routines and capabilities - individuals, interactions/processes and structure. Like Abell et al. (2008) and Barney and Felin (2013), the individual is acknowledged. However, Felin et al. (2012) equate structure to organisational structure, in contrast to the arguably more complete view of structure offered by Barney and Felin (2013). Processes as highlighted by Felin et al. refer to sequential interdependent events, which they note "maps directly to the definition of routine" $(2012, \mathrm{p}$. 1362), but they also mention that processes require individuals to be put into action.

While the above brief recounting of some literature on micro-foundations is valuable - and we will return to some parts of it later - it brings out two issues for this study. One issue is what exactly does "micro" mean? This is not something pursued in this paper, as while management accounting may be practiced by an individual (i.e. a micro perspective), it is more likely to be practiced collectively and its information disseminated to organizational members. While the role of an individual may be important, for the purposes 
of this paper, to reduce solely to the individual is likely a reduction too far (as hinted at by Barney and Felin, 2013). A second issue is one of the term "structure", which also appears to be open to interpretation. While Barney and Felin (2013) recognise the broader meaning of structures and institutions, in management accounting (and indeed accounting in general) a separation of structure from individuals is less clear cut. Accountants as individual professionals, bring structures (e.g. training, accounting rules) to an organisation. For, example, as Martínez Franco et al. (2017) suggest accountants' roles consist of structures (e.g. position within the organization, formal training) and agency (e.g. personal traits, experience) and neither necessarily has primacy. Such accounting structures may also be embodied in non-human actors such as accounting software, which may be relevant at an individual and collective level. Thus, for the purposes of this paper, while we acknowledge our use of the term "foundation" in relation to management accounting routines may be similar to the term "micro-foundations" in the broader organizational literature, there are some important distinctions as outlined. In essence, in this paper it is recognized that management accounting routines, while organizational routines, have some specific attributes such as their embeddedness in institutional structures (e.g., Englund and Gerdin, 2018; Englund et al., 2011) which we as management accounting researchers need to embody in our analysis. Thus, the term "foundations" as defined earlier is adopted to avoid conflation with the term "micro-foundations".

\subsection{Organizational routines in management accounting - founding factors}

The work of Burns and Scapens (2000) is a useful starting point to explore how routines have been used in management accounting research. A key assumption of Burns and Scapens (2000) is that the changing (or stable) nature of management accounting can be interpreted using phenomena such as rules and routines. Burns and Scapens (2000, p. 5) defined routines as "the way things are done". While less precise than Pentland (2011), it captures the importance of action. Their framework starts at the point of encoding "institutional principles into rules and routines" (2000, p. 10) and over time, new ways of doing things may evolve which will be interpreted in terms of existing rules and routines. The picture painted by Burns and 
Scapens (2000) is one of slower evolutionary change as rules and routines interact in a continuous process over time. It should be noted at this point that actors in organisations may exhibit habits. Like routines, much has been written on what constitutes habit. Hodgson (2004) cites Dewey (1922, p. 42) who states "the essence of habit is an acquired predisposition to ways or modes of response". Habits, are socially acquired, not inherited and are distinct from behaviours (Hodgson, 2004). Habits can be construed as the individual form of a routine and are thus a potential foundation of routines (Hodgson, 2008). Over time, through repetition of habits, routines may emerge (Pentland et al., 2012).

As noted in the introduction, many researchers have either drawn on Burns and Scapens (2000), offering developments of their framework, or used routines alone to explain management accounting change and/or stability. Thus, management accounting researchers generally accept organizational routines as useful to explore many aspects of management accounting. While some - such as Johansson and Siverbo (2009) or Quinn (2011) - have offered some refinements to the Burns and Scapens (2000) framework, the process of institutionalization of management accounting practices depicted therein is largely accepted. Here, we also do not delve into or challenge the process, but are interested in the beginning of this process and factors which may influence the nature of routines. To this end, some literature which provides insights into such factors is detailed, drawing on literature on management accounting routines and on general literature on organizational routines - the latter, with an eye on factors relevant to understanding the foundation of management accounting routines. In general, the management accounting literature offers a substantial body of literature on factors which affect management accounting in a given organization (e.g., AbdelKader and Luther, 2008; Chenhall, 2003; Haldma and Lääts, 2002; Herschung et al., 2017; Luft and Shields, 2003; Otley, 1980, 2016; Reid and Smith, 2000). Many of these factors may also be important for an understanding of the foundation of management accounting routines. It should be noted that the factors discussed below are not exhaustive, rather a selective synthesis of existing research on (management accounting) routines. Management accounting literature also offers a number of different approaches for organizing and classifying such factors. Such classifications mostly distinguish between factors as external 
or internal (e.g., Abdel-Kader and Luther, 2008; Haldma and Lääts, 2002), but some offer more fine-grained levels of analyses (e.g., Chenhall, 2003). We specifically draw on the classification suggested by Dillard et al. (2004). Their framework fits well here as it was intended to be used for the analysis of institutionalization processes and to address "the dynamics of enacting, embedding and changing organizational features and processes" in accounting (Dillard et al., 2004, p. 506). Dillard et al. (2004) distinguish between (i) organizational, (ii) organizational field, and (iii) economic and political levels, and below literature on each of these three levels is detailed with a focus on factors which may influence the foundations of management accounting routines. As will be detailed in Section 3, these three levels also inform the three microfoundations of routines given by Felin et al. (2012).

\subsubsection{Factors at the organizational level}

At the organizational level first, actors and their habits are cited as a foundation of organizational routines (see for example, Cohen, 2012; Felin et al., 2012; Hodgson, 2004, 2008). It is generally accepted that actors play a key role in the creation and on-going enactment of routines (see for example, Becker, 2008; Pentland, 2011) and Pentland's (2011) characteristics of routines clearly portrays the key role of (multiple) actors. More specifically, knowledge of actors may be a foundation for routines (Loch et al., 2013; Witt, 2011). Witt (2011, pp. 159-160) refers to "knowledge that is useful in solving problems, knowing how to do a job, factual and procedural knowledge relating to organizational purposes etc." and that this knowledge can be "better coordinated by organizational routines" (Witt, 2011, p. 163). In management accounting terms, important actors in the foundation of routines might be termed professional actors, i.e. professional accountants. These professional actors may be one of multiple actors required for the foundation of a routine (Pentland, 2011), and play a key role in the eventual shape a routine takes. For example, professional actors may bring knowledge based on experience or normative influences based on their professional training (cf. structures, Felin et al., 2012) to management accounting routines. Supporting this view, Marriott and Marriott (2000) note professional, external accountants are key drivers in establishing management 
accounting practices in smaller firms (see also Lavia Lopez and Hiebl, 2015).

The knowledge of non-accountant actors such as managers, employees or firm owners may also feature in foundations of management accounting routines. For instance, Burns and Scapens (2000) mention that newly appointed senior managers may require new kinds of information and thus establish new or additional routines and decisively contribute to founding these routines. Similarly, van der Steen (2011) refers to senior managers' perceived need for more elaborate controls which led to the foundation of a new management accounting routine. In the case of employees from lower ranks of the corporate hierarchy, Perren and Grant (2000) identify employees' management accounting knowledge gained from previous work experience as influencing management accounting. In the case of firm owners, for example Hiebl et al. (2013) find that family-owned firms use less management accounting practices than non-family owned firms. They interpret this finding as suggesting that controlling families have deeper tacit knowledge about their firms than other kinds of owners and thus rely less on formalized controls such as management accounting routines (see also Tsamenyi et al., 2008). This suggests non-family firm owners may be more likely to be drivers of the foundation of management accounting routines. To summarize, it appears from the literature that human actors and their knowledge in various roles is an important factor in the foundation of management accounting routines.

Actors need not be human as "in typical routines, many actants are not human" (Pentland, 2011, p. 287). Earlier works from Feldman and Pentland also support this argument (see for example, Feldman and Pentland, 2003; Pentland and Feldman, 2008; Pentland et al., 2010). Pentland et al. (2010), for example, note the percentage of actions undertaken by humans in an invoice processing routine ranged from 15 to $89 \%$ (see also Pentland, 2011). In a study of enterprise resource planning systems, Volkoff et al. (2007) introduced the concept of a material aspect of routines, which is embedded within technology (such as accounting software). As they note:

this material aspect is qualitatively different from the ostensive aspect [...] the material aspect is concrete and specific. Because it consists of transactions hard-coded into the system, it is the same for everyone, and individual interpretations do not affect how transactions are performed. At the 
same time, the material aspect is not the same as the performative aspect because the transaction is not performed but is executed by the technology. (Volkoff et al., 2007, p.840)

The distinction between "perform" and "execute" by Volkoff et al. (2007) is quite subtle, but it is an important point. Here, the presence (or not) of material routines may be a factor which affects the foundation of management accounting routines; today, it is almost inevitable that some non-human actors such as accounting software are involved in management accounting (e.g., Oliveira, 2018) - even small businesses are typically computerized in some way (Perren and Grant, 2000).

Artefacts are also a central component, not of routines per se, but as a "particularly prominent means of collecting data about routines" (Pentland and Feldman, 2005, p. 796). According to Pentland and Feldman (2005), artefacts can take many forms such as written procedures and physical settings. D'Adderio (2011, p. 197) notes the central role artefacts play "can influence [routine] emergence and persistence [and] can perform key functions, including acting as mediators and intermediaries". However, as noted by Bapuji et al. (2012), artefacts are one type of intermediary. Above, it was suggested accounting software contains material aspects of routines, but it may also be an intermediary in the sense proposed by Bapuji et al. $(2012)^{5}$. Accounting software is thus arguably an artefact, but it is also an actor. As an artefact, accounting can "transmit" an intended practice to other actors. For example, the standardised menus and icons typical to accounting software can be easily "transmitted" by management accountants (professional actors) to other actors; or accounting software/information systems can influence how management accounting works (see for example, Grabski et al., 2010; Granlund and Malmi, 2002; Oliveira, 2018; Perren and Grant, 2000; Scapens and Jazayeri, 2003). Thus, the literature provides some evidence that artefacts may serve as a foundation of management accounting routines, and displays elements of structure in the sense described

\footnotetext{
${ }^{5} \mathrm{We}$ are not intending to explore the differences between the terms non-human actor and intermediary as applied to accounting software. However, the later term is potentially more suited to a management accounting context as it is unlikely that typical management accounting tasks are "acted out" by accounting software, but tasks are "executed" (Volkoff et al., 2007).
} 
by Felin et al. (2012) and Barney and Felin (2013).

\subsubsection{Factors at the organizational field level}

As expressed by Dillard et al. (2004), the organizational field refers to the inter-organizational context in which organizations are institutionally embedded. Being part of an organizational field, Barley and Tolbert (1997, p. 93) argue that "organizations, and the individuals who populate them, are suspended in a web of values, norms, rules, beliefs, and taken-for-granted assumptions, that are at least partially of their own making." Thus, the foundation of new routines seems likely to be influenced by the organizational field. Important aspects of organizational fields include professional associations, industry trends and market competition. Their influence on the foundation of management accounting routines is now detailed.

As generally noted in new institutional sociology, in an organizational field there may be normative, mimetic or coercive pressures to behave in a certain way. Although focusing on institutions, Scott (2014) notes that institutions may form or become similar as a result of these pressures. As part of such pressures, Massini et al. (2005) argue that reference groups may significantly contribute to shaping organizational routines and such reference groups include professions and industry groups who set standards. Normative isomorphic pressure spreads new standards throughout members of the group. In the context of management accounting routines, there may be various normative pressures for professional management accountants. Such pressures may come from the management accountants' professional education or from associations of professional management accountants (Seal, 2006). For instance, the Chartered Institute of Management Accountants (CIMA) serves as both an educational institution as well as an association of management accountants. As an example, CIMA recently published an updated version of its "Code of Ethics", including clearly normative instructions for members:

As chartered management accountants CIMA members (and registered students) throughout the world have a duty to observe the highest standards of conduct and integrity, and to uphold the good standing and reputation of the profession. They must also refrain from any conduct which might discredit the profession. Members and registered students must have regard to these guidelines 
irrespective of their field of activity, of their contract of employment or of any other professional memberships they may hold. (CIMA, 2015, p. 3)

When professional management accountants lay foundations of new routines and adhere to such standards, the shape of the new routine will be - at least in part - shaped by normative pressures from professional bodies such as CIMA. In line with this notion, Greenwood et al. (2002) found that the routines of professional associations may reproduce prevailing practices (i.e. routines) in the accountants' client organizations and that the influence of professional associations is stronger in smaller accounting firms. Thus, professional accountants may be very much influenced by their education when later founding management accounting routines. From the more general literature on organizational routines, the influence of organizational outsiders (such as accountants) on the foundation of routines also receives some support. Turner and Rindova (2012) for example, note the key role of organizational outsiders in the formation of/change to new garbage collection routines.

Industry trends or standards may also be a foundation for management accounting routines. For instance, Soin et al. (2002) describe a case of a UK Bank, which - like other banks at that time - faced increased competition and cost pressures and responded with new management accounting routines. In addition to such trends, general characteristics of value creation or production technology in a given industry are likely to have an influence on the foundation of management accounting routines in specific organizations. There is ample evidence in the management accounting literature of the impact of industry sectors on the choice of management accounting practices (e.g., Abdel-Kader and Luther, 2008; Chenhall, 2003; Luft and Shields, 2003). Thus, Modell (2002) suggests that industry specifics such as technological complexity exert decisive influence on the institutionalisation of cost allocations, which may imply that such effects also exist for the wider array of management accounting practices (see also Messner, 2016). As another example, Euske and Riccaboni (1999) note that deregulation - and thus the increasingly competitive market environment - of the Italian banking market in the 1990s did not imply new management accounting routines, rather an increased focus on routines which were symbolically set up in the earlier regulated 
environment. There is also some evidence for the converse argument, i.e. that lower market competition is related to lower reliance on management accounting routines. For example, Malmi (1997) presents a case where an organizational sub-unit successfully resisted the introduction of a new management accounting routine, in part due to marginally competitive market conditions.

Factors such as those described above portray structural qualities in the sense described in the literature on micro-foundations as outlined earlier. Of course, such structural factors influence and are drawn upon by individual(s), and are thus part of an on-going interaction of structure and action. In the context of this paper, they may also be factors which influence the foundation of management accounting routines in a particular organisation.

\subsubsection{Factors at the economic and political level}

As coined by Dillard et al. (2004, p. 511), aspects of the economic and political level "make up the context within which an organization functions". They further note (p. 512) that at this level, "norms and values are established and disseminated to members of the society". Therefore, the context, norms and values - all of which are structures in the sense of Felin et al. (2012) and Barney and Felin (2013) - established at the economic and political level influence the organizational field and organizational levels. Aspects of the economic and political level which have potential to shape the foundation of management accounting routines include regulation/legislation and general economic conditions. Turning to regulation/legislation first, it is reasonable to assume that laws and regulations - such as accounting standards or company law have direct impact on how accounting information is presented (Dillard et al., 2004). While such standards could be argued to be the sphere of financial accounting, there is evidence that (de-)regulation/legislation impacts management accounting routines (e.g., Covaleski et al., 2013; Coyte et al., 2010; Hopper and Major, 2007; Tsamenyi et al., 2006; van der Steen, 2011; Wagenhofer, 2016). For instance, van der Steen (2011) presents a case in which the managers of a Dutch bank introduced a new planning and control routine, which in part was attributed to new legislation. This legislation required Dutch bank managers to 
"document that they had informed customers about all risks associated to the financial services they offered" and thus implied increased internal control (i.e. management accounting) routines. Similar evidence of legislation driving the foundation of management accounting routines can be found in Coyte et al. (2010). They report that due to legal requirements, the public sector organisation they studied had to use net-present-value calculations for capital investment projects geared towards non-commercial goals (e.g., allowing access for disabled) - despite such projects likely to yield negative net-present values. To summarize, while the influence of regulation/legislation on the foundation of management accounting routines may be perceived critically by the actors performing these routines, there is evidence that regulation/legislation may have an important impact on the foundation of such routines.

General economic conditions may also lead to regulatory or legislative changes, which later affect management accounting routines (Van der Stede, 2011), or bring about new routines. The recent financial crisis has offered some opportunity to study the impact of weakening economic conditions on management accounting. While not explicitly referring to the concept of routines, Asel et al. (2011) analyse the effect of the recent crisis on some aspects of management control. They find that the more managers faced negative crisis effects, the more they "tightened their strings" and put emphasis on liquidity and cost cutting. These results may be interpreted as managers founding new management accounting routines under weak economic conditions (e.g. liquidity controls) or shifting the focus from certain management accounting routines to others (e.g. to those that monitor liquidity or costs) (see also Becker et al., 2016). Political crises may also affect management accounting routines and the historical literature provides some evidence here. For example, Quinn and Jackson (2014) present some evidence from the First World War, noting how it led to the foundation of new management accounting routines to account for war risk costs; MedinaAlbaladejo and Menzani (2017) suggest that the Franco and Mussolini eras in Spain and Italy brought about both homogenisation and development of management accounting practices (i.e. routines). 


\section{A framework on the foundations of management accounting routines}

Above, we suggested some factors which may influence the foundations of management accounting routines. These factors, while drawn from various literatures, are not intended as an exhaustive list. However, we can begin to piece together a more comprehensive framework on the process of routinization of management accounting practices, which is depicted in Figure 1. We now describe in detail the process within Figure 1, and the next section provides some empirical data which is interpreted using it as an analytical lens.

\footnotetext{
$===========$ Insert Figure 1 here $=============$
}

Figure 1 - Foundation and routinization of management accounting practices

The right-hand box of Figure 1 portrays the combined work of Burns and Scapens (2000), Felin et al. (2012) and Quinn (2011). As noted earlier, we do not challenge with the general nature of Burns and Scapens (2000). Their framework begins with "the encoding of institutional principles into rules and routines" (ibid, p. 10), which is depicted as arrow A (but see below). While it is generally accepted that routines are a component of institutions (see for example, Barley and Tolbert, 1997; Burns and Scapens, 2000; Giddens, 1984; Hodgson, 2008; Scott, 2014), as noted in Section 2 the literature on organizational routines is diverse. Here we adopt Pentland's (2011) definition of organizational routines, and this presents us with somewhat of a conundrum when related to Burns and Scapens (2000). The starting point of Burns and Scapens (2000) assumes institutions are in-situ, and thus by definition, organizational routines also exist as these comprise the underlying repetitive actions of institutions ${ }^{6}$. As our objective is to explore the foundations of management accounting routines (which ultimately may become institutionalised practices) and factors

\footnotetext{
${ }^{6}$ Burns and Scapens (2000) depict arrow A on both sets on rule/routine interactions as portrayed on the right of Figure 1.
} 
leading to such foundations, a reverse engineering of the Burns and Scapens (2000) process is in effect required. That is, this paper works backwards from Burns and Scapens' (2000) framework - in which routines are already formed or institutionalised - to trace the origins of the routines.

The right-hand box of Figure 1 depicts a process of the eventual institutionalization of management accounting practices which, like Burns and Scapens (2000) entails repeated enacting and reproduction. In contrast to Burns and Scapens (2000), Figure 1 depicts action as beginning at an organizational level rather than taken-for-granted assumptions/institutional realm (which is represented by arrow A) they adopt. This initial action is depicted as $\mathrm{C}_{0}$ on Figure 1, within the realm of action only, signifying that actions cannot yet be termed institutionalized, or routinized (per Pentland's (2011) criteria). This is because an action cannot be regarded as a routine without sufficient repetition (Oliveira and Quinn, 2015). From this point in the process when particular management accounting action has been reproduced, it will over time through repeated enacting/reproduction (lines B and C) become a management accounting routine. Eventually, the routines may become institutionalized (lines D). And, as portrayed by Burns and Scapens (2000), these institutionalized management accounting practices will influence new rules and routines (lines A to D). Finally, as per Quinn (2011), Figure 1 portrays the interactions between rules and routines as tentative (dotted lines), in that rules may not emerge. Quinn (2011) argues that rules are artefacts of routines, in that they are a written and formal statement of how things should be done. This argument by Quinn (2011) is similar to Burns and Scapens (2000), but it does suggest routines precede rules - whereby rules are formalised and written - and this is accepted in this paper also.

Turning now to the left-hand box of Figure 1, factors which may be the foundations of the (eventual) management accounting routines - which start out at $\mathrm{C}_{0}$ as an instance of action - are depicted. Burns and Scapens (2000) acknowledge that "routines which emerge in any particular case, may be difficult to predict [but] they are not arbitrary - they can be explained" (2000, p. 12). They also note "[change] will be pathdependent, in that the existing routines and institutions will shape the selection and implementation process." (ibid). They also mention factors such as other external institutions and professionals as 
influencers. They do not however explore or explain in detail such influences and how they may interact in their process of institutionalization. Given our focus on routines as the unit of analysis, rather than institutions, the left-hand box of Figure 1 reflects factors which may influence the actions of members of an organization - such as management accountants - at point $\mathrm{C}_{0}$. We are terming this point $\mathrm{C}_{0}$, following Burns and Scapens' (2000) notation of " $\mathrm{C}$ " being a point were action occurs, that action being the reproduction of a management accounting practice by an actor. In contrast to their work, here, $\mathrm{C}_{0}$ represents initial action of an actor, rather than reproduced action, and this is elaborated on below.

Our review of the literature in Section 2 revealed factors which may shape management accounting. These factors originate from diverse literature sources, and are not intended as exhaustive (hence the three dots in each of the rectangles in the left-hand side of Figure 1). As in Section 2, the factors are categorised according to what Dillard et al. term "three levels of socio-historical relationships" (2004, p. 512) - namely economic and political, organizational field and organizational. While Dillard et al. (2004) utilise these three levels to explain a cascading effect which results in organizational level institutions, we utilise them purely as descriptive categories to assist our analysis. This is not suggesting a cascading effect does not exist, and indeed is quite likely as suggested by Dillard et al. (2004) - this is visualized by the arrows between the three levels. The left-hand box of Figure 1 depicts factors such as regulation/legislation, economic conditions, professional associations, human and non-human actors and habits. An elaborative description of each factor is not given here (but see Section 2), but some elaboration on how they may interact and emerge as a foundation for management accounting routines is necessary. As mentioned above, Burns and Scapens (2000) noted that routines are not arbitrary, may be difficult to predict are pathdependent. We agree, and the factors depicted in Figure 1 may not be able to predict the exact nature of an eventual management accounting routine. However, when action occurs at $\mathrm{C}_{0}$, being the first occurrence of a pattern of action(s) that can potentially lead to a management accounting routine, it is highly unlikely that it is random (see below also). The actor(s) will be influenced or informed by one or more of the factors. In Figure 1, potential factors are depicted as cogs. A gear mechanism is a useful analogy to convey how factors 
may work in combination to be the foundation of a management accounting routine. In any gear mechanism, there are several possible combinations of cogs which achieve one thing (assuming a power source), namely motion. Thinking of the gear mechanism in a car or on a bicycle for example, the type of motion depends on the combination of cogs - a larger cog driving a smaller cog results in faster motion and vice versa; the more cogs in a gear mechanism the greater the degrees of motion ranging from slow hill climb to fast flat terrain.

Let us relate the gear mechanism/cog analogy to Figure 1 and the foundations of management accounting routines. When actors engage in some or other management accounting task for the first time in an organization ${ }^{7}$, two things can be stated: 1) this is not yet a routine as no repetition has occurred, and 2) the actors are likely to be influenced by some factor(s) which are depicted as cogs here. The combination of cogs (factors) will influence the "motion" (or type) of management accounting practices which are likely to be reproduced. Over time, these practices may become routinized and institutionalized, and depending on the underlying foundations, what is observed as institutionalised management accounting practice may vary considerably - even in similar contexts. If, for example, a new business enters a relatively complex industry sector, industry standards may be a factor which influence the foundation of routines; or if the organization uses non-human actors such as software (with embedded material routines), the software design may be an influencing factor. For the sake of clarity, in Figure 1, each factor is shown as a cog of similar size, suggesting each factor has a similar importance in the foundations of a management accounting routine. In any given real-life organization, this is unlikely to be the case. For example, if present, the influence of a human actor in the form of a "professional accountant" on the type and sophistication of management accounting practice may deserve a larger cog in Figure 1; likewise, the non-human actor "software". Also, it is conceivable that some factors could be classified as multi-level. For example, a professional accountant not only has his/her own experience to bring to an organization, but also that his/her

\footnotetext{
${ }^{7}$ As we focus on the foundations of management accounting routines, the institutional realm within the organization does not influence its foundation as by definition the task has not yet been routinized.
} 
professional accounting body i.e. organizational field level. Similarly, an organization could conceivably develop its own software which has an influence on management accounting. Thus, in a particular instance, to correctly visually depict actual cogs which influence the foundation of management accounting routines, they may be of differing size and place than our depiction in Figure 1.

As already described, $\mathrm{C}_{0}$ in Figure 1 depicts the first occurrence of a pattern of action(s) that can potentially lead to a routine, and is influenced by factors such as those mentioned. However, action requires actors, and while actors can be human or non-human, it is likely that human actors will feature more in the foundation of management accounting routines - for example, human actors are required to initiate the installation of accounting software. Since the management accounting literature drawing on institutional theory mostly agrees that management accounting practices are embedded in structural arrangements (e.g., Englund et al., 2011; Lawrence et al., 2009; Modell, 2012; Ribeiro and Scapens, 2006), we can safely assume that also in the foundation of management accounting routines, there can be observed an interplay between individuals and structures. Human actors will draw on various structural entities, including the factors (cogs) depicted in Figure 1. Thus, $\mathrm{C}_{0}$ depicts the interaction of the individual(s) and structures they may draw upon to bring about action - that action being a first occurrence of a pattern of action(s) that can potentially result in a routine being formed. While Felin et al. (2012) suggest individuals, processes/interactions and structure as micro-foundations of routines - and individuals, interactions and structures are depicted in Figure 1 - we do not (at point $\mathrm{C}_{0}$ ) include processes. This is because what is depicted at $\mathrm{C}_{0}$ is the first occurrence of a pattern of action and is not yet a settled and accepted pattern of action. Once action has been repeated several times and is potentially routinized, through the interactions of rules and routines (lines B and C in Figure 1), then a process emerges. Prior management accounting research drawing on institutional theory has found that individuals not agreeing with newly introduced management accounting practices often respond with resistance (e.g., Hiebl 2018; Scapens and Roberts, 1993). While such resistance can result in an adaptation of the introduced management accounting practices or their outright non-application, there is also some evidence indicating that if new practices are introduced 
despite resistance, it can delay their introduction (e.g., Ashraf and Uddin, 2015; Sharma and Lawrence, 2008). We can thus assume that if there is less initial fit between the individuals and the structures involved in the foundation of management accounting routines, there is a lower chance of routinization and if routinization takes place nevertheless, this process is likely to be longer in terms of time than in situations of a high initial fit between individuals and existing structures. In Figure 1, the potential of such nonroutinization - irrespective of whether caused by resistance or other dynamics - is represented by a dashed line in the arrow from $\mathrm{C}_{0}$. Thus, $\mathrm{C}_{0}$ is tentative since the acting out of management accounting practices does not always imply they will be routinized and the process of institutionalization (right-hand side) may not occur.

To sum up, our framework depicted in Figure 1 suggests that the actual foundation of a management accounting routine happens through the interaction between individuals and structures. These structures may stem from the economic/political level, the organizational field level and/or the organizational level. If the initial fit between individuals and structures is high, we expect that routinization of management accounting is more likely and that it materializes faster than in situations of a lower initial fit between individuals and structures. In a similar way to Burns and Scapens (2000), our framework is intended to provide researchers who study management accounting as a routinized (and institutionalized) practice with an analytical tool to explore, explain and interpret the foundation of management accounting routines in an organization. Understanding the foundation of routines may help researchers gain a deeper understanding into issues such as why particular management accounting routines exist, why some organizations have more sophisticated routines despite similar contexts and how/why routines remain stable and/or change. The latter in particular may be useful to researchers and practitioners interested in management accounting change, as if the foundations of a routine can be determined as a relatively strong and powerful factor such as a professional accountant - then it may be easier to select appropriate change methods. In the next section, we utilise Figure 1 to analyse empirical data from two cases. 


\section{Highlights from empirical cases}

To illustrate what is depicted in Figure 1, we present two anonymised cases, Baby and Weavers. Both were part of a broader study of management accounting routines in small firms carried out between 2012 and 2016. Each case is presented and both are then discussed in light of Figure 1. Given our objective of analysing the foundation of management accounting routines, small firms are useful illustrations as they typically provide more detailed access than larger firms (Lavia Lopez and Hiebl, 2015; Mitchell and Reid, 2000). The broader study of these cases utilised semi-structured interviews with managers, external accountants and management accountants. Both cases were similar in terms of turnover and staff numbers, but as will be detail below Weavers is almost two decades older than Baby.

\subsection{Baby case}

Baby was incorporated in 2003, by two siblings with no previous business experience. The company develops baby and nursery products and commissions their contract manufacture. It mainly sells direct to retail outlets. The remainder of this section describes the process of management accounting change in a general sense from 2003 to the time of the research.

When Baby was formed, management accounting was as Sam (one of the founders) put it "probably accidental actually. It wasn't a big plan". No one had previous accounting knowledge and a practicing accountant, Tara, was consulted. Sam recalled "the only thing I knew about accounting was Tara". In 2003, Tara assisted in the preparation of basic cash flow and profit projections using spreadsheets. Regular business transactions (sales, purchases etc.) were also captured using spreadsheets. It quickly became apparent that cash flow was an important factor in the business as contract manufacturers required up-front payment. The two founders quickly realized the limitations of spreadsheets and within a few months, Tara 
advised them to purchase QuickBooks ${ }^{8}$ accounting software despite them being "totally alien" (Tara) to accounting. Tara recommended this product due to its relatively simple user interface and easy error correction. Thus, within the first year or so in business, Baby had established an accounting system for regular accounting transactions, the work undertaken by the two siblings for the most part.

As Sam became familiar with QuickBooks, she started to use its in-built inventory module. Baby outsourced manufacturing to the Far East, and inventory was (and still is) located in warehouses near ports ready for shipment. Sam wanted to have information on the location and quantity of inventory, as well as information on inventory on order. While QuickBooks has a functional inventory module suited to smaller business, Sam's lack of accounting expertise resulted in some oddities. Tara recalled how "there would be a gross loss, which is impossible". Thus, Tara disabled the stock control module and re-called:

They were totally frustrated by QuickBooks in that they tried to, from the very start, to integrate a stock control system on it. Now, QuickBooks has a stock control system [...] but when you have two people with no previous accounting experience, to try and integrate a stock control system is just not possible. So I had to disable it and Sam found that very frustrating, but from selfpreservation for myself I had to. For example, when we went in to do the first set of accounts, they were a mess, because she was trying to use the stock control system and it just didn't work.

At the end of the second financial year "the accounts were a disaster" (Tara). While daily transaction processing was being done, Tara described the year end situation as being poor - "there was an awful lot of stuff not reconciled, so it was poor. So there was a lot of deleting and tidying up". Tara and Sam agreed that Tara's accounting firm would now prepare bi-monthly management accounts, the objective being to keep the accounting records as accurate as possible. Thus, by late 2005/early 2006, Baby was now preparing bi-monthly financial statements.

As business grew, cash flows were an on-going issue. Research costs were substantial, and manufacturing in the Far East continued to strain cash flow. A first round of external investment occurred in 2006, when

\footnotetext{
${ }^{8}$ A common accounting software product for small business, which is designed with the lay user in mind.
} 
a combination of a state-owned business development body and private investors agreed to invest cash; a second round of investment occurred in 2011. In both instances, the investors were not actively involved in day-to-day management, but did attend board meetings. The investors requested more accounting information and required the instigation of new management accounting tasks, including detailed forecasts of activities (revenues, costs and cash-flows) and variance analysis. As the investors insisted on these items, Baby had little choice but to comply. Tara noted the investor requirements as being "over-elaborate and there was no way they could do it themselves". Thus, Tara's firm now not only prepared bi-monthly financial statements, but also budgets with regular revisions and variance analysis. The investors also insisted that Tara's practice conduct an audit of Baby, even though it complied with national audit exemption regulations.

From 2006, Baby continued to prepare bi-monthly management accounts (i.e. the key financial statements), together with (revised) budgets and variance analysis, with the assistance of Tara's firm. As the business grew, Sam and her sibling began to appreciate the value of the bi-monthly management accounting reports:

It's been good for us, because it gives us a bit more perspective and you know where you are. You know if you're on a good or if you're not, and if not, why not. Whereas if you don't do it, you tend to only think of the good, you know. Now things can crop up, every two months you go, look, you're way over budget on that. So, it keeps you in a good mind-set I suppose.

Following the second round of investment in 2011, it became clear to Tara that Baby needed a management accountant, for two reasons. First, Baby, for their size were a complex client. The investors insisted on an audit; Baby had research and development expenditure; and, Tara or a colleague assisted in the bi-monthly management reporting process. Tara described Baby as a "write off" (or loss) in terms of billable time versus the chargeable fee. Second, Tara perceived a conflict in being involved in the preparation of internal management accounts and conducting an audit. As a result, in late 2010 Dan came on board as a management accountant initially part-time, assuming a full-time role in mid-2011.

Dan had 30 years' experience as a management accountant. He worked with multinational companies and 
had experience of several accounting software products. Dan's title was Financial Controller, although he was acutely aware that a financial controller in a small business is not the same as a financial controller role in a larger organization:

When you work for an owner managed business, where the owners of the business are actively dayto-day managing the business, then you have less control of the finances than you would otherwise have, because obviously the owners are the key decision makers at the end of the day. In essence, I'm in charge of the financial system, producing the management accounts for the shareholders, and also have an input in those strategic decisions $[\ldots]$ to grow the business.

When Dan joined, he changed the accounting software to Sage ${ }^{9}$. He had previous experience with Sage and was comfortable to make the change from QuickBooks. This change to Sage also saw the inclusion of a full inventory control module, which pleased Sam. It also pleased Tara (from an audit perspective), and with Dan's accounting knowledge the system accurately reflected Baby's inventory. Other regular management accounting tasks did not change their general form. However, Dan did change how some tasks were done. For example, he changed the budgeting approach to a more accurate bottom-up approach:

I introduced that, the bottom-up approach, yes. And the advantage that that gives you then, when you're reporting your actuals against your forecast, you have a forecast by product and by customer, so you've something real to compare how are we doing by this customer and how is this product doing with this customer, how is this product doing overall, what actions do I need to take, how is my new product going.

Since I've come in, the investors obviously have made bigger and bigger demands in terms of reporting. So part of their requirements would be, to compare actuals to budget at the start of the year and there's a variance. They want more and more explanation behind that variance. So unless you build it up in such a way, bottom up, you could go back then and say well because this product is not performing or this customer is not performing, because these costs are higher than we had budgeted.

Dan noted that higher-level budget figures were entered in the Sage software to provide basic variance analysis. More detailed variance analysis used spreadsheets. The changes he made to the budgeting process

${ }^{9}$ A common UK-based accounting software product. 
were approved by the external investors before implementation. Dan also mentioned how the bi-monthly management accounts now included an executive summary and key-financial highlights such as sales by product, major variances, unbudgeted costs and inventory levels. Dan also introduced weekly meetings with sales staff and a weekly cash forecast. As Dan noted on the cash forecast "as the company grows the demand for working capital becomes increasingly more critical, so this is a control mechanism."

\subsection{Foundations of management accounting routines at Baby}

Since Baby was formed, management accounting progressed from spreadsheets to the regular provision of decision-making information using accounting software. Thus, management accounting has changed over time and likely routinized and institutionalised as suggested by Burns and Scapens (2000) and depicted on the right hand side of Figure 1. Those doing the (management) accounting tasks have moved from the founders, to a combination of external accountants/internal staff, and ultimately to a financial controller. Changes and developments were instigated by various actors - the founders themselves (frustrated with spreadsheets), external accountants (doing bi-monthly management accounts), investors (requiring detailed budgets and variances) and by the financial controller (budget improvements, weekly sales and cash reports).

Two key factors affected the foundation of management accounting routines at Baby, namely software and professional accountants - organizational factors per Figure 1, although the structures the professional accountants (Tara, Dan) brought with them as actors (i.e. knowledge and beliefs about accounting and accounting software) could also be regarded as stemming from the organizational field. In particular, the QuickBooks software package was a key foundation. As mentioned in Section 2, Volkoff et al. (2007) note that (material) routines embedded in software can assist in organizational change as they guide action - that is, the software has structural qualities. The QuickBooks software is capable of producing basic accounting reports, as well as budgets and basic variance reports. Within the first year of business, QuickBooks was being used by Baby to process regular business transactions and used by both founders. Thus, it can be 
stated that the daily transaction processing was routinized as it meets Pentland's (2011) four components as described earlier (see Section 2.1) - namely 1) repetition, transactions processed regularly, 2) a recognizable pattern of action, through the QuickBooks software, 3) interdependent actions, processing accounting transactions is by nature interdependent and 4) multiple actors, the two founders and the QuickBooks software.

However, the regular (month or year-end) internal financial statement-type reporting was not routinized, despite repetition, as they could not be deemed as part of interdependent action i.e. the reports were not used for decision-making, or in other words management accounting. Even with QuickBooks in place, Baby lacked the accounting knowledge and experience to prepare accurate monthly financial statements for decision-making purposes. That is, the individuals interacting with the software showed little initial fit with the structures embedded in QuickBooks - only the experience of an external accountant (Tara) led to a more efficient usage of the software and the production of bi-monthly management accounts - late 2005, early 2006 - which were useful for decision-making. Of course, given the very nature of accounting, a transaction processing system must be in place before financial statements can be produced, but typically input from someone with accounting knowledge is required to make such statements a fair reflection of the underlying business transactions. Thus, Tara was a key factor in the foundation of regular (bi-monthly) management accounting routines, as without Tara's professional accounting knowledge the regular internal reports would not have been produced.

As mentioned, two key factors which formed the foundations of management accounting routines at Baby were accounting software (QuickBooks) and professional actors. Relating these to Figure 1, software is depicted as organizational on the left side. For Baby, as QuickBooks is a general software product used by many businesses, it is reasonable to also depict this as an organisational level influence. In Figure 1, human actors are also depicted (such as professional accountants) at the organizational level. In Baby, this was not (yet) the case, as arguably Tara was not part of the organization, but as suggested above the role of Tara as a professional accountant could also be classified at the organizational field level. Thus, from the founding 
to the company in 2003 to late 2005/early 2006, while accounting was being "practised" and we have noted above that the transaction processing element of accounting may have been routinized, management accounting was not routinized. That is, in terms of Figure 1, the necessary interaction between the founders (i.e. individuals) and the accounting software (i.e. structures) in use was flawed, as the founders had insufficient knowledge and experience in using this software. Only around late 2005/early 2006, when this interaction was improved, a combination of individuals (Tara, the founders) and structures (QuickBooks software) - organizational and organizational field factors - interacted to lay foundations of management accounting routines. That is, only then point $\mathrm{C}_{0}$ on Figure 1 was attained since all three cogs as parts of $\mathrm{C}_{0}$ (i.e. individuals, interactions, structures in the form of accounting software) were present. From then, bimonthly management accounts were prepared and used for decision-making/management accounting purposes and became routinized through repetition over time (the first set of arrows B and C in Figure 1). That is, at the time when professional actors entered the scene, the fit between the three cogs as part of arrow $\mathrm{C}_{0}$ was high, which can explain why the bi-monthly accounts were routinized quickly. In turn, the low fit between individuals (i.e. the founders) and structures (i.e. accounting software) before professional actors came in can explain why no management accounting routines materialized.

It is also apparent that, later as Baby grew, external investors played a key role in the (re-)shaping of management accounting routines, but after the foundations were in place as described above. Investors required more and regular accounting information, which ultimately led to the hiring of Dan. With his experience, additional budgeting tasks were added, which would not have been possible without existing routines in place. Although Dan changed how things were done, and there are some new management accounting practices, the overall practices (bi-monthly management accounts and reports) remained stable. While Dan and the Sage software shaped the present-day management accounting routines, they can be considered in conjunction with the foundations described above (QuickBooks and Tara). In 2011 when Dan became full-time staff, the present-day routines received their shape based on existing routines - that is, in Figure 1, there was a move from the left-hand set of arrows B and C to the right-hand set - as outlined by 
Burns and Scapens (2000).

To summarize the Baby case in terms of Figure 1, it is clear that the two key factors were software - a nonhuman actor - and (professional) human actors. Together, the professional accounting individuals and the structures embedded in the QuickBooks software (both foundations) resulted in routinization of management accounting at the end of 2005/early 2006. At this time, in terms of Figure 1, the three cogs as part of $\mathrm{C}_{0}$ were present and led to the first set of arrows B and C. These existing routines then were the basis for later change in 2011 (second set of arrows B and C). However, Baby is a single case and to add some substance to this, a further case is now detailed, namely Weavers.

\subsection{Weavers case}

Weavers was founded in 1985 as a joint venture with a textile firm "Yarn". Yarn's general manager, Kirk, and Weaver's founder, Rob, each held 25\% of the shares and Yarn held 50\%. At this time, Weavers operated as a contract manufacturer to Yarn, as Herb (the current Managing Director of Weavers) explained:

Back in the 1980s, Yarn enjoyed incoming orders of 70,000 meters or so per month. And they did not really know how to cope with this demand and produce sufficient quantities. This enabled a very smooth start for our firm. We simply produced a certain number of meters per month and it went lovely.

However, increased internationalization of the weaving business and a general shift to manufacturing in Asia left Yarn bankrupt in 1995. At this time, Herb held 50\% of the shares - after insolvency proceedings this increased to $75 \%$. By 2012, Herb and his wife, Rose, had 100\% ownership. Thus, in contrast to most small businesses (Dyer and Handler, 1994), Weavers evolved to be a typical, owner-managed small firm only over time. By the time of this research, $70 \%$ of Weavers' turnover was exported to other European countries and $30 \%$ to overseas markets (mostly USA and Japan). Two-thirds of turnover are standard products, the balance being custom fabrics.

Until 1995, the vast majority of Weaver's sales were to Yarn. Therefore, Weaver's manager at that time 
(Kirk) had little need for management accounting information as he was part of Yarn's management team. Thus, there were no dedicated full-time administrative staff. However, Rose and Herb recalled that in the early days, monthly management reports were produced by an external accountant. The reports consisted of an income statement and lists of payable and receivables and were used to see whether the past month was in line with expectations. However, expectations were not formalized as monthly budgets. Instead, they calculated fixed costs for the entire year to be covered by sales and compared monthly accounts to fixed costs to assess if the latter were sufficiently covered. To relate sales to fixed costs, Kirk had introduced a basic calculation scheme which is still used today in a more developed form.

Since 1985, the same accounting firm has provided the above mentioned monthly management reports and according to Herb, the structure of the statements has not changed. Nobody at Weavers questioned the structure of these reports, as Herb put it:

I think these accounts are standardized. I think our accounting firm produces these accounts in the same structure for their other clients.

With the bankruptcy of Yarn in 1995, Herb and Rose (the management team) of Weavers, moved the business focus from contract manufacturing towards building their own market position. However, to make product offers to customers, they needed more detailed cost information. According to Herb, the cost allocation method still used today relies on a basic structure introduced by Kirk, Weavers' former business manager. However, over time Herb has gained more experience and the complexity of Weavers' product portfolio has increased significantly, resulting in a more complex (but similar) calculation. Herb could not fully recall how or when their current cost allocation method was introduced:

Our calculation scheme, well this dates back a long time. It was initially introduced by Kirk, our former business manager, when our firm was started. After having taken over the majority in the firm, we also found it useful and this is how I started using it.

The method can be outlined as follows. At the beginning of the year, Herb budgets the annual fixed costs 
from past income statements provided by the external accountant. However, estimating budget sales for the year is more difficult and Herb notes that sales cannot really be planned in Weavers' business sector:

In our business, we cannot plan sales. You know that the more you are out there, the more customer contacts you get. But what really translates into sales is still unpalatable and at risk. So we cannot plan what customers really order with us or which individual projects will happen.

Thus, Herb focuses on the extent Weavers' machines were utilized last year and calculates the necessary utilization to cover all fixed costs for the coming year. Herb obtains the number of shots ${ }^{10}$ used last year, and using this he plans total shots for the coming year and divides the fixed costs by the shots number. The result is a fixed cost per shot, and in turn, the number of shots to cover fixed costs. When Herb has finished these annual calculations, he knows the break-even number of machine shots to be attained:

I have to cover our fixed costs and I have to work on selling enough fabrics and reach a certain amount of gross margin. If I achieve this and the sooner I achieve this, it is great because from then on, we make profit. For instance, if I reach the breakeven point at the end of October, I have got two full months to create profits for the year, and then it starts being really interesting.

To track when they reach the breakeven point, Herb and Rose use the monthly management reports provided by their external accountant. These monthly income statements and payables/receivables list are now prepared by Herb, Rose, Norah (an internal accountant) and the external accountant. Before the actual statements are provided, Norah collects incoming and outgoing invoices for the month, puts them into folder and delivers them manually to the external accountant. A few days later, the external accountant sends the monthly reports to Herb and Rose, who then analyse and compare the numbers to the previous month and the same month last year.

\footnotetext{
${ }^{10}$ A shot refers to a single pass of thread or yarn from one side of a web (a width of fabric being woven) to the other. This number is recorded on the weaving machines.
} 


\subsection{Foundations of management accounting routines at Weavers}

As with Baby, some human actors are key factors in explaining the foundation of management accounting routines at Weavers. First is Kirk, who brought broad industry experience with him to Weavers. He laid the basis for the cost calculation method still in use today. Second is the external accountant/accounting firm, who have provided Weavers with financial statements since its inception. We can deem the cost calculation and the monthly financial reports as management accounting routines as per Pentland (2011), as the four components of routines (see Section 2.1) are present, namely 1) repetition, regularly produced reports, 2) a recognizable pattern of action, similar reports produced monthly, 3) interdependent actions, accounting documents collated within Weavers, sent to the external accountant, back to managers for decision-making use, and 4) multiple actors, Herb, Rose, Norah (internal accountant) and the external accountant.

While the financial statements prepared by the external accountant do not appear to be overly useful, they are regularly produced and are an input to the cost calculations, and thus they represent the interdependency component of the routine. As indicated by Herb's comments, both Kirk and the external accountants used their specific knowledge (weaving in the case of Kirk, accounting in the case of the accountants) and influenced the foundation of management accounting routines. As Herb's statements above exemplify, his impression of the way the accounts are prepared by the external accountant reflects an "industry standard" in accounting. The weaving sector itself also encompassed certain standards. The calculation scheme which dates back to Kirk's influence reflected an industry standard practice at the time and Herb indicated that sales planning in the industry was always difficult.

Thus, with reference to left side of Figure 1, human actors at an organizational level (Kirk and the external accountant) interacted with industry standards at the organizational field level in the foundation of management accounting routines at Weavers - i.e. the cost calculation and the monthly income statements. The two key human actors of course encompassed elements of structure (accounting expertise and training, industry standards and knowledge). Thus, in contrast to Baby, at Weavers the organizational field level is more at play, through accepted industry standards of cost calculation and production scheduling. These 
organizational field level factors incorporating structure - industry standards and knowledge - interacted with Kirk (an individual) within the organization. Since Kirk was an experienced weaving industry manager at the time when the management accounting routines were founded, he showed a high degree of fit with the structures in the organizational field level. As far as could be retrieved from our interviewees' memories, this high degree of fit in the interaction between individuals and structures, which represents the three cogs as part of the $\mathrm{C}_{0}$ arrow in Figure 1, resulted in a quick routinization of the respective practices - that is, the fixed-cost-per-shot practice and the reports from the external accountants ${ }^{11}$ quickly became routinized. The exact point in time when Weavers can be depicted at $\mathrm{C}_{0}$ on Figure 1 is not certain, but it was at an early stage in the life of the company and the resulting routines have remained relatively stable since then. In contrast to Baby, there have been no major changes to the routines (e.g. no new software, no new professional accounting staff). Thus, the repeated enacting of the routines at Weavers would be depicted by the left-hand set of arrows B and C on Figure 1, and not move across to the second set as at Baby.

\subsection{Differing foundations, differing management accounting routines}

As revealed above, the management accounting routines are different in the two cases presented. Differences in management accounting between two cases could be expected, given the different industry context for example, or the experiences of various actors in each case. Arguably, the Baby case presented more sophisticated management accounting routines - it prepares more detailed budgets, manages cash flows, uses accounting software and employs a professional accountant. In contrast, management accounting at Weavers is less complex, with little or no accounting information produced or used internally. What management accounting there is at Weavers is routinized however. To explain the differences, our framework presented in Figure 1 has been useful.

\footnotetext{
11 The external accountants, while influencing the foundation of routines, did not partake in action within the organization.
} 
As detailed in previous sections, the foundations of management accounting routines in two cases revolve around different factors. These factors have been revealed from the case data using Figure 1 as a lens, allowing us to reflect on, categorise and isolate the key factors. The management accounting routines formed in both cases were founded on particular factors, and then the interactions of individual and structural elements embodied within these factors (i.e., the three $\operatorname{cogs}$ in the $\mathrm{C}_{0}$ arrow in Figure 1) brought about routines. We can explain, through Figure 1, why Baby would appear to have apparently more sophisticated management accounting routines. The primary factor was the use of accounting software from an early stage of the company's development i.e. software was a key foundation of the routines. Although Tara was an important actor at Baby initially and a founding factor, the accounting software brought structures to Baby (i.e. the software encompasses accounting principles and processes) which influence how the company operated. These structural properties of the accounting software could then be drawn on by individuals to create, maintain or change management accounting with the company - and as noted above, Baby arguably made a shift across Figure 1 to a new set of routines when Dan arrived. In contrast, Weavers did not utilise any such accounting software and was not influenced by structures within any accounting software.

What also becomes evident through the analysis of our cases in light of Figure 1 is that in the Baby case, the initially low fit between the $\mathrm{C}_{0} \operatorname{cogs}$ in Figure 1, that is individuals (i.e., the founders) and the accounting structures in place (i.e., QuickBooks software), resulted in a non-routinization of management accounting practices. This routinization only took place when individuals showing a better fit with the accounting structures (i.e., the professional accountants Tara and Dan) became part of the action. In contrast, at Weavers, while generally featuring less sophisticated management accounting practices than Baby today, there was already a high initial fit between the individual in charge (i.e., Kirk) and the respective organizational field level structures, resulting in a quick routinization of management accounting practices. In summary, Figure 1 has allowed us to focus in on key factors and their interactions which resulted in eventual management accounting routines at two cases. This in turn allowed us to identify and explain key 
differences in the foundations of these routines, which offers some explanation for the nature of present day management accounting routines (although this not an objective of this paper). It also highlights from the two cases that the process of routinization of management accounting with firms can vary in time, and this variation can be (at least partially) explained by the foundations of these same routines. Having such knowledge and understanding may assist researchers to explain why, for example, an organisation is more willing or unwilling to change its management accounting routines. Such examples point towards how the work presented here may be used in future research, which is detailed in the next section.

\section{Concluding comments}

The objective of this paper is to provide an understanding of the foundation of management accounting routines, and it brings together much extant research on routines in the organizational and management accounting literature. We now briefly discuss the framework presented through Figure 1, focussing on what it means for future management accounting research.

To begin, we could ask, how does the framework improve our understanding of management accounting routines? Considering the empirical aspect first, namely the two illustrative cases, without the framework, factors and the interactions between factors which contributed to the shape of the present-day routines would be less apparent. The framework has allowed us to identify factors more prevalent in founding (and subsequently shaping in the Baby case in particular) management accounting routines. These factors, as shown in the cases, are likely to vary within organizations, and some will be more influential than others. For example, in Baby the relatively stronger influence of professional actors is apparent, whereas in Weavers industry standards were more influential. For future empirical research, the process depicted in Figure 1 provides a prompting to researchers to explore the nature of management accounting routines in a holistic way - in particular, to understand and interpret existing routines in the context of factors and interactions between factors underpinning their foundation. As Quinn (2014) notes, some routines may be 
sticky over time, a conclusion derived by exploring one aspect of management accounting over a prolonged time period. Similarly, Figure 1 should prompt researchers to think about the foundations of routines as they seek to interpret and explain present day management accounting routines in organisations.

What is presented in Figure 1 also adds a conceptual/theoretical understanding. In essence, by bringing together various strands of literature, a more comprehensive framework of the process which results in management accounting routines is given. From this, we can suggest several avenues for further research. First, research on what additional factors influence the foundations of routines would be useful, as the list depicted in Figure 1 is not exhaustive. Second, it would be interesting to further explore the processes of founding and forming of routines. A particularly interesting aspect here may be how long it takes for management accounting routines to form and what path they take (i.e. reach $\mathrm{C}_{0}$ ) - as seen in the two cases here, it would seem to vary. Similarly, the relative influence of each factor could be explored, seeking out commonalities and differences across organizations. The cases presented here suggest accounting software as a foundation may result in more sophisticated management accounting routines over time. It would also be interesting to study the influence of founding factors on the stability of management accounting routines over time, as to effectively change management accounting routines, it may be necessary to understand their foundations. The framework depicted in Figure 1 may therefore also be interesting to the further study of stability and change of management accounting routines. Finally, further empirical research corroborating the proposition that a higher degree of fit between acting individuals and structures results in a quicker routinization of the respective management accounting practices would be useful.

The work presented here has some limitations. First, two cases are used to exemplify the work. These represent typical small firms, but are insufficient in number to draw major conclusions. Thus, more case research is needed to broaden, deepen and possibly question the argumentation presented here. Third, although Figure 1 is portrayed as a process over time, the case data is from interviews at a point in time. Although staff at the cases gave us the history of their organizations over time in some detail, it would probably be even more insightful to actually observe routines form and emerge. Thus, research on 
management accounting routines as they form and emerge over time would be fruitful. Fourth, as noted, our list of factors which may affect the foundations of management accounting routines is not exhaustive. Consequently, more empirical research on such factors and the interactions between factors, or how and why some may be more influential than others is encouraged.

To finish, we have provided an understanding on the foundations of management accounting routines which can be used by researchers as a tool to explain, understand and interpret how and why routines are shaped the way they are. We encourage its use in more real-life settings, where its usefulness and/or limitations will be highlighted.

\section{References}

Abell, P., Felin, T. and Foss, N. (2008), "Building micro-foundations for the routines, capabilities, and performance links", Managerial and Decision Economics, Vol. 29 No. 6, pp. 489-502.

Abdel-Kader, M. and Luther, R. (2008), "The impact of firm characteristics on management accounting practices: A UK-based empirical analysis", The British Accounting Review, Vol. 40 No. 1, pp. 2-27.

Asel, J.A., Posch, A. and Speckbacher, G. (2011), "Squeezing or cuddling? The impact of economic crises on management control and stakeholder management", Review of Managerial Science, Vol. 5 No. 23, pp. 213-231.

Ashraf, J. and Uddin, S. (2015), "Military, 'managers' and hegemonies of management accounting controls: A critical realist interpretation", Management Accounting Research, Vol. 29, pp. 13-26.

Bapuji, H., Hora, M. and Saeed, A.M. (2012), "Intentions, Intermediaries, and Interaction: Examining the Emergence of Routines", Journal of Management Studies, Vol. 49 No. 8, pp. 1586-1607.

Barley, S.R. and Tolbert, P.S. (1997), "Institutionalisation and structuration: studying the links between action and institution", Organization Studies, Vol. 18 No. 1, pp. 93-117.

Barney, J. and Felin, T. (2013), "What are microfoundations?", Academy of Management Perspectives, Vol. 27 No. 2, pp. 138-155.

Becker, M.C. (2008), "The past, present and future of organizational routines”, in: Becker, M.C. (Ed.), Handbook of Organizational Routines. Edward Elgar, Cheltenham, pp. 15-28.

Becker, M.C. (2005), "The concept of routines: some clarifications", Cambridge Journal of Economics, Vol. 29 No. 2, pp. 249-262.

Becker, M.C., Lazaric, N., Nelson, R.R. and Winter, S.G. (2005), “Applying organizational routines in understanding organizational change", Industrial and Corporate Change, Vol. 14 No. 5, pp. 775-791.

Becker, S.D., Mahlendorf, M.D., Schäffer, U. and Thaten, M. (2016), "Budgeting in times of economic crisis", Contemporary Accounting Research, Vol. 33 No. 4, pp. 1489-1517. 
Burns, J. and Scapens, R. (2000), "Conceptualising management accounting change: an institutional framework", Management Accounting Research, Vol. 11 No. 1, pp. 3-25.

Busco, C. and Scapens, R.W. (2011), "Management accounting systems and organisational culture: Interpreting their linkages and processes of change", Qualitative Research in Accounting \& Management, Vol. 8 No. 4, pp. 320-357.

Chenhall, R.H. (2003), "Management control systems design within its organizational context: findings from contingency-based research and directions for the future", Accounting, Organizations and Society, Vol. 28 No. 2, pp. 127-168.

CIMA (2015), CIMA code of ethics for professional accountants. Available at http://www.cimaglobal.com/Documents/Professional\%20ethics\%20docs/2015\%20code $\% 20$ of $\% 20$ et hics/CIMA_Code_of_Ethics_15.pdf No. last accessed February 9 (2015).

Cohen, M.D. (2012), "Perceiving and Remembering Routine Action: Fundamental Micro-Level Origins", Journal of Management Studies, Vol. 49 No. 8, pp. 1383-1388.

Covaleski, M.A., Dirsmith, M.W. and Weiss, J.M. (2013), "The social construction, challenge and transformation of a budgetary regime: The endogenization of welfare regulation by institutional entrepreneurs", Accounting, Organizations and Society, Vol. 38 No. 5, pp. 333-364.

Coyte, R., Emsley, D. and Boyd, D. (2010), "Examining management accounting change as rules and routines: the effect of rule precision", Australian Accounting Review, Vol. 20 No. 2, pp. 96-109.

D'Adderio, L. (2011), "Artifacts at the centre of routines: performing the material turn in routines theory", Journal of Institutional Economics, Vol. 7 No. 2, pp. 197-230.

Dewey, J. (1922), Human nature and conduct: An introduction to social psychology. Holt, New York.

Dillard, J.F., Rigsby, J.T. and Goodman, C. (2004), "The making and remaking of organization context: duality and the institutionalization process", Accounting, Auditing \& Accountability Journal, Vol. 17 No. 4, pp. 506-542.

Dyer, W.G. and Handler, W. (1994), "Entrepreneurship and Family Business: Exploring the Connections", Entrepreneurship Theory and Practice, Vol. 18 No. 3, pp. 71-83.

Englund, H. and Gerdin, J. (2018), "Management accounting and the paradox of embedded agency: A framework for analyzing sources of structural change", Management Accounting Research, Vol. 38, pp. 1-11.

Englund, H., Gerdin, J., and Burns, J. (2011), " 25 years of Giddens in accounting research: achievements, limitations and the future", Accounting, Organizations and Society, Vol. 36 No. 8, pp. 494-513.

Euske, K.J. and Riccaboni, A. (1999), "Stability to profitability: managing interdependencies to meet a new environment", Accounting, Organizations and Society, Vol. 24 No. 5, pp. 463-481.

Feldman, M.S. and Pentland, B.T. (2003), "Re-conceptualizing organizational routines as a source of flexibility and change", Administrative Science Quarterly, Vol. 48 No. 1, pp. 94-118.

Felin, T., Foss, N.J., Heimeriks, K.H. and Madsen, T.L. (2012), "Microfoundations of routines and capabilities: Individuals, processes, and structure", Journal of Management Studies, Vol. 49 No.8, pp. 1351-1374.

Fiondella, C., Macchioni, R., Maffei, M. and Spanò, R. (2016), "Successful changes in management accounting systems: A healthcare case study”, Accounting Forum, Vol. 40 No. 3, pp. 186-204.

Giddens, A. (1984), The Constitution of Society. Polity Press, Cambridge.

Grabski, S., Leech, S. and Sangster, A. (2010), Management Accounting in Enterprise Resource Planning. CIMA, London. 
Granlund, M. and Malmi, T. (2002), "Moderate impact of ERPS on management accounting: a lag or permanent outcome?”, Management Accounting Research, Vol. 13 No. 3, pp. 299-321.

Greenwood, R., Suddaby, R. and Hinings, C.R. (2002), "Theorizing change: The role of professional associations in the transformation of institutionalized fields", Academy of Management Journal, Vol. 45 No. 1 , pp. 58-80.

Haldma, T. and Lääts, K. (2002), "Contingencies influencing the management accounting practices of Estonian manufacturing companies", Management Accounting Research, Vol. 13 No. 4, pp. 379-400.

Hassan, M.K. (2005), "Management accounting and organisational change: an institutional perspective", Journal of Accounting \& Organizational Change, Vol. 1 No. 2, pp. 125-140.

Herschung, F., Mahlendorf, M.D. and Weber, J. (2017), "Mapping Quantitative Management Accounting Research 2002-2012", Journal of Management Accounting Research, forthcoming, doi: $10.2308 /$ jmar-51745.

Hiebl, M.R.W. (2018), "Management accounting as a political resource for enabling embedded agency", Management Accounting Research, Vol. 38, pp. 22-38.

Hiebl, M.R.W., Feldbauer-Durstmüller, B. and Duller, C. (2013), "The changing role of management accounting in the transition from a family business to a non-family business", Journal of Accounting \& Organizational Change, Vol. 9 No. 2, pp. 119-154.

Hoad, T.F. (1993), The Concise Oxford Dictionary of English Etymology. Oxford University Press, Oxford.

Hodgson, G. (2004), "Reclaiming habit for institutional economics", Journal of Economic Psychology, Vol. 25 No. 5, pp. 651-660.

Hodgson, G. (2008), “The concept of a routine”, in: Becker, M.C. (Ed.), Handbook of Organizational Routines. Edward Elgar, Cheltenham, pp. 15-28.

Hopper, T. and Major, M. (2007), "Extending Institutional Analysis through Theoretical Triangulation: Regulation and Activity-Based Costing in Portuguese Telecommunications", European Accounting Review, Vol. 16 No. 1, pp. 59-97.

Jabbour, M. and Abdel-Kader, M. (2015), "Changes in capital allocation practices-ERM and organisational change", Accounting Forum, Vol. 39 No. 4, pp. 295-311.

Johansson, T. and Siverbo, S. (2009), "Why is research on management accounting change not explicitly evolutionary? Taking the next step in the conceptualisation of management accounting change", Management Accounting Research, Vol. 20 No. 2, pp. 146-162.

Kilduff, M. (1992), "Performance and interaction routines in multinational corporations", Journal of International Business Studies, Vol. 23 No. 1, pp. 133-145.

Lavia Lopez, O. and Hiebl, M.R.W. (2015), "Management Accounting in Small and Medium-Sized Enterprises: Current Knowledge and Avenues for Further Research", Journal of Management Accounting Research, Vol. 27 No. 1, pp. 81-119.

Lawrence, S., Sharma, U. and Nandan, R. (2009), "Giving institutional theory a critical edge: a study of systems change in a Fijian housing authority", International Journal of Critical Accounting, Vol. 1 No. 4, pp. 390-405.

Loch, C.H., Sengupta, K. and Ahmad, M.G. (2013), "The Microevolution of Routines: How Problem Solving and Social Preferences Interact", Organization Science, Vol. 24 No. 1, pp. 99-115.

Lukka, K. (2007), "Management accounting change and stability: loosely coupled rules and routines in action", Management Accounting Research, Vol. 18 No. 1, pp. 76-101.

Luft, J. and Shields, M.D. (2003), "Mapping management accounting: graphics and guidelines for theoryconsistent empirical research", Accounting, Organizations and Society, Vol. 28 No. 2, pp. 169-249. 
Malmi, T. (1997), “Towards explaining activity-based costing failure: accounting and control in a decentralized organization”, Management Accounting Research, Vol. 8 No. 4, pp. 459-480.

Marriott, N. and Marriott, P. (2000), "Professional accountants and the development of a management accounting service for the small firm: barriers and possibilities", Management Accounting Research, Vol. 11 No. 4, pp. 475-492.

Martinez Franco, C., Feeney, O., Quinn, M., and Hiebl, M.R.W. (2017), "Position practices of the presentday CFO: A reflection on historic roles at Guinness, 1920-1945", Revista de Contabilidad, Vol. 20 No.1, pp. 55-62.

Massini, S., Lewin, A.Y. and Greve, H.R. (2005), "Innovators and imitators: Organizational reference groups and adoption of organizational routines", Research Policy, Vol. 34 No. 10, pp. 1550-1569.

Medina-Albaladejo, F.J. and Menzani, T. (2017), "Co-operative Wineries in Italy and Spain in the Second Half of the Twentieth Century: Success or Failure of the Co-operative Business Model?", Enterprise \& Society, Vol. 18 No. 1, pp. 32-71.

Messner, M. (2016), "Does industry matter? How industry context shapes management accounting practice", Management Accounting Research, Vol. 31, pp. 103-111.

Mitchell, F. and Reid, G.C. (2000), "Editorial. Problems, challenges and opportunities: the small business as a setting for management accounting research", Management Accounting Research, Vol. 11 No. 4, pp. 385-390.

Modell, S. (2002), "Institutional perspectives on cost allocations: integration and extension", European Accounting Review, Vol. 11 No. 4, pp. 653-679.

Modell, S. (2012), "Strategy, political regulation and management control in the public sector: institutional and critical perspectives", Management Accounting Research, Vol. 23 No. 4, pp. 278-295.

Oliveira, J. (2018), “Accountants' roles and accounting-related technologies”, in: Quinn, M. and Strauss, E. (Eds.), The Routledge Companion to Accounting Information Systems. Routledge, Abingdon, pp. 133-144.

Oliveira, J. and Quinn, M. (2015), "Interactions of rules and routines: re-thinking rules", Journal of Accounting \& Organizational Change, Vol. 11 No. 4, pp. 503-526.

Otley, D.T. (1980), “The contingency theory of management accounting: achievement and prognosis", Accounting, Organizations and Society, Vol. 5 No. 4, pp. 413-428.

Otley, D. (2016), "The contingency theory of management accounting and control: 1980-2014", Management Accounting Research, Vol. 31, pp. 45-62.

Pentland, B.T. (2011), "The foundation is solid, if you know where to look: comment on Felin and Foss", Journal of Institutional Economics, Vol. 7 No. 2, pp. 279-293.

Pentland, B.T. and Feldman, M.S. (2008), "Issues in empirical field studies of organizational routines", in: Becker, M.C. (Ed.), Handbook of Organizational Routines. Edward Elgar, Cheltenham, pp. 281-300.

Pentland, B.T. and Feldman, M.S. (2005), "Organizational routines as a unit of analysis", Industrial and Corporate Change, Vol. 14 No. 5, pp. 793-815.

Pentland, B.T., Feldman, M.S., Becker, M.C. and Liu, P. (2012), "Dynamics of Organizational Routines: A generative model", Journal of Management Studies, Vol. 49 No. 8, pp. 1484-1508.

Pentland, B.T., Haerem, T. and Hillison, D. (2010), "Comparing organizational routines as recurrent patterns of action", Organization Studies, Vol. 31 No. 7, pp. 917-940.

Perren, L. and Grant, P. (2000), "The evolution of management accounting routines in small businesses: a social construction perspective", Management Accounting Research, Vol. 11 No. 4, pp. 391-411.

Quinn, M. (2014), "Stability and change in management accounting over time: A century or so of evidence 
from Guinness”, Management Accounting Research, Vol. 25 No. 1, pp. 76-92.

Quinn, M. (2011), "Routines in Management Accounting research: further exploration", Journal of Accounting \& Organizational Change, Vol. 7 No. 4, pp. 337-357.

Quinn, M. and Jackson, W.J. (2014), “Accounting for war risk costs: management accounting change at Guinness during the First World War", Accounting History Review, Vol. 24 No. 2-3, pp. 191-209.

Reid, G.C. and Smith, J.A. (2000), “The impact of contingencies on management accounting system development”, Management Accounting Research, Vol. 11 No. 4, pp. 427-450.

Ribeiro, J.A. and Scapens, R.W. (2006). "Institutional theories in management accounting change: contributions, issues and paths for development", Qualitative Research in Accounting \& Management, Vol 3 No. 2, pp. 94-111.

Scapens, R.W. (2006), "Understanding management accounting practices: A personal journey”, The British Accounting Review, Vol. 38 No. 1, pp. 1-30.

Scapens, R.W. and Jazayeri, M. (2003), "ERP systems and management accounting change: opportunities or impacts? A research note”, European Accounting Review, Vol. 12 No. 1, pp. 201-233.

Scapens, R.W. and Roberts, J. (1993), "Accounting and control: a case study of resistance to accounting change", Management Accounting Research, Vol. 4 No. 1, pp. 1-32.

Scott, W.R. (2014), Institutions and Organizations - Ideas, Interests, and Identities. Sage, Thousand Oaks.

Seal, W. (2006), "Management accounting and corporate governance: An institutional interpretation of the agency problem", Management Accounting Research, Vol. 17 No. 4, pp. 389-408.

Sharma, U. and Lawrence, S. (2008), "Stability and change at FPTL: An institutional perspective", Australian Accounting Review, Vol. 18 No. 1, pp. 25-34.

Sharma, U., Lawrence, S., and Lowe, A. (2010), "Institutional contradiction and management control innovation: A field study of total quality management practices in a privatized telecommunication company", Management Accounting Research, Vol. 21 No. 4, pp. 251-264.

Sharma, U., Lawrence, S. and Lowe, A. (2014), "Accountants as institutional entrepreneurs: changing routines in a telecommunications company", Qualitative Research in Accounting \& Management, Vol. 11 No. 3, pp. 190-214.

Siti-Nabiha, A.K. and Scapens, R.W. (2005), "Stability and change: an institutionalist study of management accounting change", Accounting, Auditing \& Accountability Journal, Vol. 18 No. 1, pp. 44-73.

Skeat, W.W. (1993), The Concise Dictionary of English Etymology. Wordsworth Editions, Ware.

Soin, K., Seal, W. and Cullen, J. (2002), "ABC and organizational change: an institutional perspective", Management Accounting Research, Vol. 13 No. 2, pp. 249-271.

Spraakman, G. (2006), "The impact of institutions on management accounting changes at the Hudson's Bay Company, 1670 to 2005”, Journal of Accounting \& Organizational Change, Vol. 2 No. 2, pp. 101122.

Tsamenyi, M., Cullen, J. and González, J.M.G. (2006), "Changes in accounting and financial information system in a Spanish electricity company: A new institutional theory analysis", Management Accounting Research, Vol. 17 No. 4, pp. 409-432.

Tsamenyi, M., Noormansyah, I. and Uddin, S. (2008), "Management controls in family-owned businesses No. FOBs): A case study of an Indonesian family-owned University", Accounting Forum, Vol. 32 No. 1, pp. 62-74.

Turner, S. and Rindova, V. (2012), "A Balancing Act: How Organizations Pursue Consistency in Routine Functioning in the Face of Ongoing Change", Organization Science, Vol. 23 No. 1, pp. 24-46. 
Van der Stede, W.A. (2011), "Management accounting research in the wake of the crisis: some reflections", European Accounting Review, Vol. 20 No. 4, pp. 605-623.

van der Steen, M. (2009), "Inertia and management accounting change: The role of ambiguity and contradiction between formal rules and routines", Accounting, Auditing \& Accountability Journal, Vol. 22 No. 5, pp. 736-761.

van der Steen, M. (2011), "The emergence and change of management accounting routines", Accounting, Auditing \& Accountability Journal, Vol. 24 No. 4, pp. 502-547.

Volkoff, O., Strong, D.M. and Elmes, M.B. (2007), "Technological Embeddedness and Organizational Change", Organization Science, Vol. 18 No. 5, pp. 832-848.

Wagenhofer, A. (2016), "Exploiting regulatory changes for research in management accounting", Management Accounting Research, Vol. 31, pp. 112-117.

Witt, U. (2011), "Emergence and functionality of organizational routines: an individualistic approach", Journal of Institutional Economics, Vol. 7 No. 2, pp. 157-174. 